\title{
SUSPENSIÓN DE LA PRESCRIPCIÓN DE LA ACCIÓN DE RESPONSABILIDAD EXTRACONTRACTUAL. ANÁLISIS DOGMÁTICO Y JURISPRUDENCIAL
}

\author{
SUSPENSION OF THE ACTION FOR NONCONTRACTUAL \\ LIABILITY'S PRESCRIPTION. DOGMATIC AND \\ JURISPRUDENTIAL ANALYSIS
}

DIEGO GALINDO MANRÍQUEZ*

\section{RESUMEN}

El presente trabajo tiene por objeto analizar el problema consistente en determinar si es que el plazo de prescripción de la acción de responsabilidad extracontractual admite o no suspensión. Para ello, en primer lugar, se examinarán los fundamentos y aspectos generales de la institución de la suspensión, así como de los artículos que convergen en el problema planteado; luego, se examinará críticamente el estado actual del problema, tanto en la doctrina nacional, como en la jurisprudencia de la Excelentísima Corte Suprema de los últimos 10 años, consignando finalmente mi opinión respecto de las posiciones en conflicto.

Palabras clave: Responsabilidad extracontractual, Prescripción, Suspensión del plazo de prescripción, Acción de responsabilidad extracontractual, Jurisprudencia de la Corte Suprema, Derecho civil.

* Abogado, Licenciado en Ciencias Jurídicas y Sociales, Universidad de Concepción. Magíster en Derecho Privado, Universidad de Concepción. Correo electrónico: dgalindo@udec.cl. Código Orcid: https://orcid.org/0000-0002-7719-9009.

Este artículo se basa en la tesis del mismo nombre realizada por el autor en el Magíster en Derecho Privado de la Universidad de Concepción, que fue dirigida por el profesor Manuel Barría Paredes. 


\section{ABSTRACT}

The overall aim of this study is to analyze the problem in determining if the prescription deadline of the action for noncontractual liability admits suspension or not. To that end, first, the foundations and general aspects of the institution of the suspension, as well as of the articles that converge in the posed problem, are going to be reviewed. Then, the current state of the issue, both in the national doctrine and in the Supreme Court last ten year jurisprudence, is critically analyzed to finally state my opinion concerning the conflicting positions.

Keywords: Noncontractual liability, Prescription, Suspension of the prescription period, Noncontractual liability action, Supreme Court jurisprudence, Civil law.

\section{INTRODUCCIÓN}

La acción que emana de la comisión de un delito o cuasidelito civil, conforme a lo dispuesto en el artículo 2332 del Código Civil, prescribe en cuatro años contados desde la perpetración del acto.

Al respecto, tradicionalmente se suele enseñar que el referido plazo de prescripción, al tener una extensión inferior a cinco años y al estar regulado en un título especial del Código (Título XXXV del Libro IV) - fuera del título en que se regulan las reglas generales de la prescripción extintiva - es calificable, conforme al artículo 2524 del mismo texto, como "prescripción especial de corto tiempo". ${ }^{1}$

Acto seguido, se suele agregar que al no establecerse en el Código una norma especial que disponga expresamente que dicha prescripción se suspenda a favor de determinadas personas, aquel plazo de prescripción no admitiría suspensión alguna a su respecto (conforme al artículo 2524, el cual dispone que las prescripciones especiales de corto tiempo corren en contra de toda persona, salvo regla contraria).

Sin embargo, la jurisprudencia desde hace algún tiempo no ha sido

\footnotetext{
${ }^{1} \mathrm{Al}$ respecto puede verse, entre otros: Alessandri, Arturo, De la responsabilidad extracontractual en el derecho civil chileno, Imprenta Universitaria, Santiago, 1943, n ${ }^{\circ} 435$, p. 538; FuEYo, Fernando, Derecho Civil, Imprenta Universo, Santiago, 1958, T. IV, p. 270 y 271.
} 
consistente con la tesis expuesta, sino que, al contrario, en ciertas ocasiones ha llegado a sostener, en contra de aquel dogma que parecía casi absoluto, que la prescripción de la acción de responsabilidad extracontractual se suspende conforme a la regla general de suspensión de la prescripción extintiva contenida en el artículo 2520 del Código Civil.

Así, la jurisprudencia dejaría en evidencia dos grandes posiciones: que, para algunos, dicha prescripción no admite suspensión, pues la califican como especial de corto tiempo; en tanto que para otros ésta sí se suspendería, pues no tendría el carácter de especial de corto tiempo y, por lo tanto, regiría a su respecto la regla general en materia de suspensión de la prescripción extintiva anteriormente señalada.

Cabe tener presente que no se trata de un tema superficial el resolver si es que la referida prescripción admite o no suspensión, sino que, muy por lo contrario, éste es de vital importancia, pues la aplicación de una u otra posición trae aparejadas consecuencias significativas para las personas que fueren víctimas de un hecho ilícito que les causó daño y estuvieren comprendidas en los números 1 y 2 del artículo 2509 del Código Civil.

Para graficar la importancia del problema, piénsese en la siguiente hipótesis: Pedro, con fecha 01/10/2000, debido al actuar negligente de un tercero, sufre un accidente fatal que le causa la muerte, dejando como heredero a un hijo menor, de 10 años cumplidos en igual fecha, llamado Juan. En esta hipótesis, la acción de Juan para demandar al tercero, por ejemplo, por el daño moral sufrido como víctima por repercusión por la muerte de su padre, prescribiría, conforme al artículo 2332 del Código Civil, en principio, con fecha 01/10/2004; sin embargo, si se estima que a su respecto ha operado la suspensión de la prescripción extintiva, contemplada en el artículo 2520 en relación al artículo $2509 \mathrm{~N}^{\mathrm{o}} 1$, por tratarse de un menor, la prescripción recién comenzará a correr cuando Juan llegue a la mayoría de edad (el 01/10/2008) prescribiendo finalmente el 01/10/2012. Naturalmente, el asunto tendrá importancia para el caso en que Juan entable la acción después de transcurridos los primeros cuatro años (con posterioridad al 01/10/2004), por ejemplo, durante el año 2009, caso en el cual el demandado, autor del daño, se defendería oponiendo la excepción de prescripción extintiva, sosteniendo que, la prescripción del artículo 2332 al tratarse de un plazo de prescripción especial de corto tiempo, conforme al artículo 2524, no se ha suspendido a favor del demandante, por lo que su acción se encuentra prescrita y debe ser rechazada; en cambio, Juan retrucaría aquel planteamiento indicando que, en su opinión, la prescripción del artículo 2332 no es calificable de especial de corto tiempo y que, por lo tanto, sí se ha suspendido a su favor, conforme a 
la regla general prevista en el artículo 2520, encontrándose vigente la acción al momento en que entabló su demanda, pues según las normas que cita, la acción recién prescribiría a su respecto con fecha 01/10/2012.

Como queda demostrado, la cuestión tiene relevancia cuando la acción es ejercida por una persona comprendida en alguna de las causales de suspensión a las que se remite el artículo 2520, después de transcurridos los primeros 4 años contados desde la perpetración del acto; situación en que seguir una u otra postura, determinará, en gran medida, el éxito o fracaso de la acción de responsabilidad extracontractual.

Así, ante este panorama surgen las siguientes preguntas: ¿Qué ha sostenido la doctrina al respecto?; ¿Cuál es el estado actual de la discusión en la jurisprudencia de la Corte Suprema?; y, por último: ¿Qué tesis es la que ofrece la solución más conforme con nuestra legislación civil?

\section{METODOLOGÍA}

Para resolver esta cuestión, comenzaré por examinar los aspectos fundamentales de la suspensión de la prescripción extintiva, así como de las disposiciones legales que convergen en el problema planteado (artículos 2524, 2332, 2520 y 2509 del Código Civil).

Una vez hecho lo anterior, expondré las principales posiciones que se distinguen al respecto, tanto en la doctrina como en la jurisprudencia nacional.

Finalmente, me haré cargo, según mi opinión, de la forma más adecuada de abordar el problema, así como de las razones más consistentes para acoger o desechar la suspensión de la prescripción del artículo 2332 del Código Civil.

\section{ASPECTOS GENERALES DE LA SUSPENSIÓN DE LA PRESCRIP- CIÓN Y DE LAS NORMAS INVOLUCRADAS EN LA DISCUSIÓN}

1. Algunas consideraciones en cuanto a la institución de la suspensión de la prescripción extintiva

Planiol y RIPERT sostenían, "la prescripción se suspende cuando la ley le impide correr en beneficio de una persona". ${ }^{2}$

${ }^{2}$ Planiol, Marcel; RIPERT, Georges, Tratado práctico de derecho civil francés, Cultural S.A., La Habana, 1936, T. III, p. 693. 
Si bien el Código Civil no contiene una definición de la institución en comento, ésta suele ser definida por nuestros autores, con base a lo dispuesto en los artículos 2509 y 2520 del Código Civil, como un beneficio. A modo de ejemplo, el profesor Ramos Pazos, refiriéndose a la suspensión de la prescripción extintiva, la define como "un beneficio especial que la ley otorga a determinadas personas - las indicadas en el artículo $2509 \mathrm{~N}^{\mathrm{o}} 1$ y 2 del Código Civil - de que no corra el plazo de prescripción en su contra". ${ }^{3}$

Precisado el concepto, en cuanto a sus aspectos generales, es necesario tener en consideración los siguientes:

\subsection{El fundamento de la institución se encuentra en razones de equidady} de protección a ciertas personas

Como indica el profesor Domínguez ÁGuila "el fundamento de la suspensión es siempre una razón de equidad para con quienes, sea por razones personales, o morales, sea por otras circunstancias, no están en condiciones de interrumpir la prescripción y por lo mismo se justifica su inercia en el ejercicio del derecho". ${ }^{4}$

En el mismo sentido, se suele indicar que los fundamentos de la suspensión se encuentran íntimamente relacionados con los de la prescripción misma, ya que si bien esta última se funda en la inactividad y en la negligencia del acreedor en la custodia de sus derechos, esta situación no es óbice a que existan personas imposibilitadas de tomar por sí mismas las providencias o medidas convenientes para aquella custodia, resultando justo que la ley las ponga a cubierto de la prescripción que pudiere correr en su contra, mientras dure su impedimento o incapacidad. ${ }^{5}$

\subsection{La suspensión es un beneficio jurídico}

La gran mayoría de los autores nacionales identifica a la suspensión de la prescripción como un beneficio jurídico, es decir, un favor otorgado por ley a determinadas personas.

\footnotetext{
${ }^{3}$ Ramos, René, De las obligaciones, Legal Publishing, Santiago, 2008, $3^{\circ}$ ed. actualizada, p. 475; en el mismo sentido, Domínguez, Ramón, La Prescripción Extintiva, doctrina y jurisprudencia, Editorial Jurídica de Chile, Santiago, 2004, p. 319; ConTreras, Luis, "De la prescripción extintiva civil", memoria de prueba, Universidad de Chile, Santiago, publicada, 1945, p. 165; y a propósito de la prescripción adquisitiva: PeñaIlILlo, Daniel, Los bienes la propiedad y otros derechos reales, Editorial Jurídica de Chile, Santiago, 2006, p. 418.

${ }^{4}$ Domínguez, cit. (n. 3), p. 319.

${ }^{5}$ Contreras, cit. (n. 3), p. 165 y 166.
} 
En este sentido, su carácter de beneficio o favor legal se funda en su propio efecto, pues la suspensión exime de las consecuencias de la prescripción a determinadas personas, en razón de la especial situación en que se encuentran, previamente determinada por el legislador.

Al respecto se ha sostenido que, en nuestro derecho, la suspensión de la prescripción - a diferencia de lo que ocurría en el derecho francés donde la institución se fundaba en la máxima "contra non valentem agere non currit praescriptio"- no se basa en el principio que al impedido no le corre término, sino que ha sido una concesión legislativa a favor de las personas enumeradas al efecto, entre quienes no se comprende a los ausentes, siendo sus causales de aplicación de índole restrictiva. ${ }^{6}$

\subsection{La suspensión es un beneficio personalísimo}

La suspensión de la prescripción beneficia únicamente al favorecido con la misma. Por ello, para el caso en que existiesen varios acreedores de una misma obligación (pluralidad activa), sólo quedan amparados por la suspensión aquellos expresamente favorecidos por la ley, teniendo en cuenta que, si la propiedad del crédito cambia de titular (por ejemplo, por una cesión de créditos), el beneficio no pasa al nuevo acreedor.

En otros términos, si eventualmente -resolviéndose el problema investigado- se llegase a determinar la procedencia de la suspensión respecto a la prescripción de la acción de responsabilidad extracontractual, se debería sostener tajantemente que, para el caso de existir varias víctimas de un mismo hecho ilícito, entre las que figure alguna beneficiada con el instituto, la suspensión sólo beneficia a aquellas indicadas por la ley, mas no al resto.

En suma, su ámbito subjetivo de eficacia no es erga omnes. En este sentido los profesores Domínguez Águila, ${ }^{7}$ Abeliuk Manasevich ${ }^{8}$ y Rioseco ENRÍQUEZ, ${ }^{9}$ entre otros.

\footnotetext{
${ }^{6}$ Contreras, cit. (n. 3), p. 167.

${ }^{7}$ Domínguez, cit. (n. 3), p. 320.

${ }^{8}$ Abeliuk, René, Las Obligaciones, Editorial Jurídica de Chile, Santiago, 2007, $5^{\circ}$ Edición actualizada, T.II, p. 1223.

${ }_{9}^{9}$ Rioseco, Emilio, La Prescripción Extintiva ante la Jurisprudencia, Editorial Jurídica de Chile, Santiago, 1994, p. 88.
} 


\subsection{La suspensión es una figura excepcional}

Al ser la prescriptibilidad de las acciones la regla general en nuestro ordenamiento, todas aquellas instituciones que pugnen con dicho principio constituyen una figura de excepción. ${ }^{10}$

A este respecto, es necesario tener presente que una de las reglas comunes a toda prescripción, contenida en el artículo 2497 del Código Civil, prescribe que la prescripción corre por igual contra toda clase de personas. Por lo tanto, la regla inversa, es decir, la suspensión (situación en la cual la prescripción no corre en contra de ciertas personas), pasa a ser la excepción en nuestro medio, pues implica que respecto a determinadas personas se prolonguen los plazos de prescripción. ${ }^{11}$

La conclusión precedente se encuentra también en armonía con la función estabilizadora de la prescripción, pues es sabido que nuestro legislador ha querido que las situaciones jurídicas inciertas se consoliden con el transcurso del tiempo. Por lo mismo, figuras como la imprescriptibilidad y la suspensión constituyen excepción en nuestro derecho.

En razón de lo expuesto, se suele sostener que la suspensión es una institución de aplicación e interpretación restrictiva. ${ }^{12}$

\subsection{El efecto de la suspensión consiste en la detención del plazo de prescripción}

Tal como ha quedado enunciado, el efecto de la suspensión consiste en detener el cómputo del plazo de prescripción, o bien impedir el inicio del mismo, a favor de ciertas personas, el cual continuará corriendo útilmente una vez que cese la causa legal que originó la suspensión, cuestión que se desprende claramente del artículo 2509 inciso primero del Código Civil, a propósito de la prescripción adquisitiva ordinaria.

Por lo tanto, si es que con anterioridad a que se configurase la causal de suspensión, la prescripción ya hubiese alcanzado a correr algún tiempo, éste no se pierde, sino que, al contrario, se agrega al plazo que continuará corriendo una vez que cese la causal de suspensión.

Así las cosas, la suspensión, a diferencia de la interrupción, detiene, pero no extingue la prescripción.

\footnotetext{
${ }^{10}$ Alessandri, Arturo; Somarriva, Manuel, Los bienes y los derechos reales, Editorial Nascimento, Santiago, $1974,3^{\circ}$ ed. ampliada y actualizada, p. 560.

${ }^{11}$ Ramos, cit. (n. 3), no 622, p. 454.

${ }^{12}$ Contreras, cit. (n. 3), p. 167; Abeliuk, cit. (n. 8), p. 1223.
} 
1.6. El Código Civil chileno, tratándose de la prescripción extintiva, reguló la suspensión de la prescripción en el mismo párrafo en que están tratadas las prescripciones extintivas de largo tiempo (párrafo $3^{\circ}$ del Título XLII del Libro IV del Código Civil)

La suspensión es una institución aplicable tanto a la prescripción adquisitiva ordinaria (artículos 2509 y 2511), ${ }^{13}$ como a la prescripción extintiva (artículo 2520).

Ahora bien, es importante destacar, para el pronunciamiento que se emitirá respecto al problema en estudio, que el estatuto de la suspensión de la prescripción extintiva (artículo 2520 del Código Civil) se encuentra emplazado en el mismo párrafo en que el Código trató las prescripciones extintivas de largo tiempo (artículos 2514 y siguientes), razón que ha llevado a cierta doctrina, como se expondrá más adelante, a indicar que únicamente se aplicaría respecto de aquellas, mas no tratándose de las denominadas prescripciones de corto tiempo y prescripciones especiales de corto tiempo, las cuales se rigen por reglas especiales (artículos 2521 y siguientes del Código Civil).

\section{Algunas consideraciones en cuanto a las disposiciones legales en conflicto}

En mi opinión, determinar si la suspensión de la prescripción se aplica o no a la prescripción de la acción de responsabilidad extracontractual, depende en gran medida de la interpretación que se dé respecto de los artículos 2524 (que establece la regulación general de las prescripciones especiales de corto tiempo), 2332 (que regula el plazo de prescripción de la acción de responsabilidad extracontractual) y 2520 en relación a los números $1^{\mathrm{o}}$ y $2^{\circ}$ del 2509 (que regulan la suspensión de la prescripción extintiva), todos del Código Civil.

Los aspectos fundamentales de estas normas serán analizados a continuación y tomados en consideración al momento de emitir mi pronunciamiento.

\footnotetext{
${ }^{13}$ Sin embargo, tratándose de la prescripción adquisitiva, se ha discutido el alcance de la expresión contemplada en el inciso final del artículo 2509 a propósito de la prescripción entre cónyuges. Al respecto puede verse: PeÑaILILlo, cit. (n. 3), p. 419 y 420.
} 
2.1. Aspectos generales de la regulación de las prescripciones especiales de corto tiempo en el Código Civil (artículo 2524) con especial referencia al artículo 2332 del mismo cuerpo legal

El Código Civil chileno le dedica una exigua disposición genérica a esta clase de prescripciones. En efecto, su artículo 2524 es la única norma encargada de regularlas genéricamente. Dicha disposición reza lo siguiente: "Las prescripciones de corto tiempo a que están sujetas las acciones especiales que nacen de ciertos actos o contratos, se mencionan en los títulos respectivos, y corren también contra toda persona; salvo que expresamente se establezca otra regla".

Ahora bien, respecto de esta norma, es necesario destacar los siguientes puntos:

1. El artículo se encuentra ubicado en el párrafo $4^{\circ}$ (denominado "De ciertas acciones que prescriben en corto tiempo") del Título XLII ("De la prescripción") del Libro IV del Código Civil, luego del tratamiento de las prescripciones de corto tiempo propiamente tales contempladas en los artículos 2521 a 2523.

2. Como señala su texto, se refiere a "prescripciones de corto tiempo" a las que están sujetas las acciones especiales, sin definir que debe entenderse por tales prescripciones.

Sin embargo, en general, se ha estimado por la doctrina común que la prescripción será de corto tiempo cuando su duración es inferior a la general fijada para las acciones ordinarias en el artículo 2515 del Código Civil, esto es, 5 años. ${ }^{14}$ Así también lo ha entendido la jurisprudencia. ${ }^{15}$

Además, como señala el texto de la norma, estas prescripciones se encuentran diseminadas en los diversos títulos respectivos del Código Civil, fuera del título de la prescripción.

Fundamentalmente, es en razón de estas dos características (su corto plazo y su especialidad en la regulación) que la doctrina las ha bautizado como "prescripciones especiales de corto tiempo".

3. Por otra parte, el referido artículo sostiene que las prescripciones especiales son aquellas cuyas acciones nacen de "ciertos actos o contratos".

\footnotetext{
${ }^{14}$ Domínguez, cit. (n. 3), p. 363; Ramos, cit. (n. 3), p. 475.

${ }^{15}$ Este razonamiento se contiene en diversas sentencias de los tribunales superiores, véase, por ejemplo: Corte Suprema, 21 de junio de 2017, Rol No 101.758-2016 (cons. $4^{\circ}$ ). Misma doctrina en tiempos pretéritos en: Corte de Apelaciones de Santiago, 7 de julio de 1988, R.D.J., T. 85, sec. 2, p. 63.
} 
Como se expondrá más adelante, el alcance de esta expresión ha sido discutido tanto en la doctrina como por la jurisprudencia, pues para algunos la norma únicamente se estaría refiriendo a las acciones emanadas de actos jurídicos, quedando excluidas, por consiguiente, aquellas que emanan de meros hechos jurídicos; en cambio para otros, comprendería a ambas categorías.

4. Como otro aspecto de la cuestión, es necesario tener presente, como ya se dijo, que esta es la única disposición que disciplina, en forma general, a las denominadas "prescripciones especiales de corto tiempo".

De este breve tratamiento normativo se advierte que no existe referencia alguna a la interrupción que pueden sufrir esta clase de prescripciones. En razón de lo anterior, y teniendo a la vista el texto del artículo 2523 que otorga reglas de interrupción exclusivas a las prescripciones allí tratadas, no cabe más que concluir que es la regla general del artículo 2518 la que rige a su respecto en materia de interrupción.

5. Finalmente, es necesario agregar que es doctrina mayoritaria en nuestro medio el sostener que la expresión empleada por el codificador al señalar "corren también contra toda persona; salvo que expresamente se establezca otra regla" se refiere a que estas prescripciones no admiten suspensión alguna, salvo disposición expresa. ${ }^{16}$ Dos ejemplos clásicos de esta última situación excepcional se encontrarían a propósito de los cuadrienios para impetrar las acciones de nulidad relativa (en los artículos 1691 y 1692) y de reforma de testamento (artículo 1216).

\subsection{Algunas consideraciones respecto del artículo 2332 del Código Civil}

El artículo 2332, que establece el plazo de prescripción de la acción de responsabilidad extracontractual, dispone lo siguiente:

"Las acciones que concede este título por daño o dolo, prescriben en cuatro años contados desde la perpetración del acto".

En cuanto a su texto, estimo que es necesario tener presente lo siguiente:

1. Como enseña Barrientos Grandón, la regla tiene su origen en el artículo 2496 del Proyecto de Código de 1853, cuyo texto indicaba que "las acciones que concede este título por daño o dolo, prescriben en dos años

\footnotetext{
${ }^{16} \mathrm{Al}$ respecto véase, por ejemplo, MezA, Ramón, Manual de derecho civil: de las obligaciones, Editorial Jurídica de Chile, Santiago, 2007, p. 245; Ramos, cit. (n. 3), p. 475.
} 
contados desde el día en que la persona a quien competen tuvo conocimiento del daño o dolo; pero en todo caso podrá oponerse a ellas una prescripción de cinco años", redacción que se mantendría incólume en el "Proyecto Inédito". Finalmente, en el Proyecto de 1855 pasó a la redacción definitiva de su texto actual. ${ }^{17-18}$

2. Si bien el artículo alude a las acciones que concede el título XXXV por "daño o dolo", pudiendo pensarse que su texto únicamente se refiere a las acciones emanadas de un delito civil, jurisprudencia y doctrina han entendido que la norma se refiere a toda acción para exigir la reparación de un daño extracontractual, ya sea causado con dolo o culpa. ${ }^{19}$

3. Actualmente, el artículo consagra un plazo de prescripción de 4 años. De este modo, se advierte que se trata de un plazo menor al contemplado en el artículo 2515 para las acciones que emanan de obligaciones personales ordinarias (de 5 años contados desde que la obligación se hizo exigible) y que, por lo tanto, atendiendo al factor tiempo y a lo indicado por la doctrina común, considerando su extensión, se trataría de una de las denominadas "prescripciones especiales de corto tiempo" quedando comprendida en el texto del artículo $2524 .{ }^{20}$

4. Según la norma, el cuadrienio se cuenta desde "la perpetración del acto". En este punto, es necesario considerar que, en nuestra doctrina y jurisprudencia, la expresión ha generado controversia respecto de dos importantes materias:

4.1. La determinación del momento a partir del cual se debe computar el plazo, cuando el daño proveniente del hecho ilícito se manifiesta tiempo después de este último. A este respecto, se conocen dos posiciones claramente antagónicas, cuestión que escapa al objeto de este trabajo y que ha sido tratado latamente por la doctrina y jurisprudencia nacional; ${ }^{21}$

4.2. Por otra parte, se discute si es que la expresión "acto" utilizada por la norma queda o no comprendida dentro de la expresión "actos o contratos" empleada por el legislador en el artículo 2524 al regular las prescripciones

\footnotetext{
${ }^{17}$ Barrientos, Javier, Código Civil, concordancias, historia de la ley, jurisprudencia, Legal Publishing, Santiago, 2012, p. 1073.

${ }^{18}$ Para ahondar en la historia del precepto: Domínguez, cit. (n. 3), p. 365 y 366.

${ }^{19}$ Corte de Apelaciones de Santiago, 5 de diciembre de 2011, Legal Publishing: 56905.

${ }^{20}$ Tratándose de la diferencia de plazo existente entre las diversas acciones, se sostiene que no existen razones evidentes que justifiquen la diferencia, y que la cuestión obedece más bien a una tradición acuñada desde el derecho romano, más que a otra explicación. (DomínguEz, cit. (n. 3), p. 365).

${ }^{21}$ Al respecto puede verse: Vergara, José, “Aceptación jurisprudencial de la doctrina de que la
} 
especiales de corto tiempo. Así, la determinación de lo anterior resulta de relevancia para definir si la prescripción extracontractual es o no calificable de especial de corto tiempo. Se volverá sobre este problema más adelante.

5. Finalmente, es necesario agregar que no se contempla en el artículo 2332 - ni en ningún otro precepto del Código - una regla especial que señale que el plazo de prescripción de la acción de responsabilidad extracontractual se suspende.

En razón de lo anterior, y relacionándolo a primera vista con lo dispuesto en el texto del artículo 2524, éste constituiría otro argumento para concluir que "corre contra toda persona" y que, por lo tanto, no admite suspensión alguna.

2.3. Aspectos generales de la regulación de la suspensión de la prescripción extintiva en el Código Civil (artículo 2520 en relación a los números $1^{\circ}$ y $2^{\circ}$ del artículo 2509 del mismo Código)

Como ya fue señalado, la suspensión de la prescripción extintiva en materia civil se encuentra regulada de manera general en el artículo 2520 del Código de Bello. La referida norma reza lo siguiente:

"La prescripción que extingue las obligaciones se suspende a favor de las personas enumeradas en los números $1^{\circ}$ y $2^{\circ}$ del artículo 2509. Transcurridos diez años no se tomarán en cuenta las suspensiones mencionadas en el inciso precedente".

A su respecto, es necesario tener en consideración las siguientes prevenciones:

1. La norma se encuentra ubicada en el párrafo $3^{\circ}$ ("De la prescripción

prescripción extintiva de la responsabilidad extracontractual empieza a correr desde la perpetración del acto ilícito y no a contar de la producción del daño", en: Corral, H. (ed.), Prescripción extintiva. Estudios sobre su procedencia y funcionamiento en Derecho Público y Privado, Cuadernos de extensión jurídica 21, Universidad de los Andes, Santiago, 2011, p. 25-26; ElorriagA, Fabián, "Del día de inicio del plazo de prescripción de una acción indemnizatoria cuando el perjuicio se ha manifestado con posterioridad al hecho que lo origina", en: Corral, H. (ed.), Prescripción extintiva. Estudios sobre su procedencia y funcionamiento en Derecho Público y Privado, Cuadernos de extensión jurídica 21, Universidad de los Andes, Santiago, 2011, p. 39-60; Domínguez, Ramón, "Comentarios de jurisprudencia. Prescripción en materia de responsabilidad extracontractual: Momento de inicio del cómputo. Art. 2332 del Código Civil. Perpetración del acto. Distinción entre hecho ilícito y daño. Daños continuados", Revista de Derecho Universidad de Concepción, 2001, nº 210, p. 331-343; FERRADA, Luis, "La interpretatio per aliam legem como regla para definir el sentido del artículo 2332 del Código Civil, sobre prescripción de la acción de responsabilidad extracontractual", Revista de Derecho Escuela de Postgrado, 2012, $\mathrm{N}^{\mathrm{o}} 2$, p. 35-60. 
como modo de extinguir las acciones judiciales") del Título XLII (“De la prescripción") del Libro IV del Código Civil.

Llama la atención que el legislador la haya regulado en el mismo párrafo en que trató las prescripciones extintivas de largo tiempo (artículos 2514 y siguientes), lo que permitiría sugerir, en una primera lectura, que sólo se aplica a su respecto, mas no tratándose de prescripciones de corto tiempo, ni de las denominadas especiales de corto tiempo. Por otra parte, considerando lo señalado en los artículos 2523 inciso 1 y 2524 (tratados en el párrafo $4^{\circ}$ "de ciertas acciones que prescriben en corto tiempo"), se llegaría a la misma conclusión. Este será un punto que deberá tenerse en consideración al momento de abordar la discusión.

Con todo, como sostenía Contreras Aburto,

"no hay duda alguna en cuanto a que la suspensión de la prescripción extintiva se produce siempre en relación a las acciones ordinarias, o sea, a la prescripción de largo tiempo. En efecto, el artículo 2520, ubicado en el párrafo que trata en particular de la prescripción como medio de extinguir las acciones ordinarias, ejecutivas, accesorias de obligación y acciones propietarias, es de aplicación general para todas estas". ${ }^{22}$

2. El artículo se refiere a la prescripción que "extingue las obligaciones" Para nuestra doctrina dicha expresión se debe a un error del legislador, en cuanto lo que se extingue por prescripción extintiva es la acción, mas no la obligación, pues en conformidad al artículo $1470 \mathrm{~N}^{\circ} 2$ las obligaciones civiles extinguidas por la prescripción se transforman en naturales. ${ }^{23}$

3. La norma únicamente concede el beneficio de la suspensión a las personas enumeradas en los números 1 y 2 del artículo 2509, esto es, a favor de:

"1 Los menores; los dementes; los sordos o sordomudos que no pueden darse a entender claramente; y todos los que estén bajo potestad paterna, o bajo tutela o curaduría; y

$2^{\circ}$ La mujer casada en sociedad conyugal mientras dure ésta".

En otros términos, el artículo 2520 no se remite a todo lo preceptuado en el artículo 2509, por lo tanto, no se aplica a la herencia yacente, ni tampoco

\footnotetext{
22 Contreras, cit. (n. 3), p. 168.

${ }^{23}$ Abeliuk, cit. (n. 8), p. 1188; Ramos, cit. (n. 3), p. 443.
} 
rige a su respecto lo dispuesto en los demás acápites de la disposición (v. gr. 2509 in fine).

Por lo demás, en lo que atañe a los menores, éstos gozan del beneficio estén o no emancipados y, en el mismo sentido, tratándose de los dementes y los sordos o sordomudos que no puedan darse a entender claramente, se les concede el beneficio estén o no bajo interdicción, pues la norma no distingue.

Así las cosas, relacionando los citados numerales del artículo 2509 con el artículo 2520, es posible sostener, en términos generales, que tratándose de la prescripción extintiva, gozan del beneficio de la suspensión aquellas personas que por su capacidad, condición o estado no tienen la libre administración de sus bienes.

Atendido a lo expuesto en este punto, es factible sostener que en la suspensión de la prescripción extintiva existe un acentuado carácter subjetivo, pues tiene por objeto proteger a ciertas personas en razón de la especial situación en que se encuentran.

4. La disposición reconoce que el beneficio de la suspensión no es ad aeternum, pues dispone en su inciso segundo que "transcurridos diez años no se tomarán en cuenta las suspensiones mencionadas en el inciso precedente".

En este punto, cabe destacar que nuestro Código originalmente contemplaba en dicho inciso un plazo de 30 años. Posteriormente, con la Ley $N^{\circ} 6.162$, de 28 de enero de 1938, pasó a ser de 15 años; y finalmente, con la Ley $\mathrm{N}^{\mathrm{o}} 16.952$, del $1^{\circ}$ de octubre de 1968, a la cual debe su actual texto, se redujo a 10 años.

Por lo demás, este plazo máximo de suspensión es similar a los consagrados en los artículos 1692 inciso 2 y 1757 inciso 4, constituyendo una manifestación de la intención del codificador de consolidar las situaciones jurídicas, otorgándoles certeza.

IV. EL ESTADO DE LA CUESTIÓN ANTE LA DOCTRINA Y JURISPRUDENCIA NACIONAL

Analizada la institución de la suspensión de la prescripción, así como las normas comprometidas, conviene ahora hacerse cargo del estado actual del problema ante nuestros autores y tribunales.

Para tal efecto, primero expondré la cuestión ante la doctrina nacional, para luego entrar a analizar la jurisprudencia de nuestro máximo tribunal 
durante los últimos 10 años.

\section{El problema ante la doctrina nacional: materia de tesis contrapuestas}

De la lectura realizada de la doctrina autorizada sobre la materia, es posible extraer las siguientes conclusiones:

1. En lo que respecta a textos de doctrina que aborden el tema, reconociendo expresamente que exista discusión jurisprudencial respecto a la aplicación de la institución, éstos pueden ser calificados como poco abundantes.

En efecto, la mayoría de los manuales de Derecho Civil autorizados en la materia, sin reconocer ni advertir que el tema puede resultar discutido, se decantan por calificar derechamente a la prescripción del artículo 2332, como una prescripción especial de corto tiempo, indicando que, en virtud del artículo 2524, no se suspende. En este sentido, se han pronunciado los profesores Alessandri Rodríguez, ${ }^{24}$ Barros Errázuriz, ${ }^{25}$ Fueyo Laneri, ${ }^{26}$ Meza Barros, ${ }^{27}$ Ramos Pazos, ${ }^{28}$ Abeliuk Manasevich, ${ }^{29}$ Tapia Suárez, ${ }^{30}$ TAPIA ORTIZ, ${ }^{31}$ y en similar línea, pero con una prevención tratándose de la prescripción entre cónyuges, al profesor RoDRíGUEz GREz. ${ }^{32}$

Estimo que este tratamiento es atribuible a las fechas de publicación de sus respectivos trabajos, pues en ese entonces no se había presentado con tanto ahínco el problema en la jurisprudencia nacional.

2. Sin perjuicio de lo anterior, existen importantes autores - aunque como se dijo, pocos en cuanto a número - que, reconociendo y exponiendo sucintamente que la aplicación de la suspensión de la prescripción del artículo 2332 resulta discutida, emiten un breve pronunciamiento al respecto.

\footnotetext{
${ }^{24}$ Alessandri, cit. (n. 1), p. 538.

${ }^{25}$ Barros, Alfredo, Curso de derecho civil, Editorial Nascimento, Santiago, 1932, $4^{\circ}$ edición corregida y aumentada, T. II, p. 319-323.

${ }^{26}$ FueYo, cit. (n. 1), p. 270 y 271.

${ }^{27}$ Meza, cit. (n. 16), p. 245.

${ }^{28}$ Ramos, René, De la responsabilidad extracontractual, Legal Publishing, Santiago, 2009, $5^{\circ}$ ed., p. 124.

${ }^{29}$ AbeliuK, cit. (n. 8), T.I, p. 325 y 326.

30 TAPIA SuARez, Orlando, "La responsabilidad extracontractual (continuación)", Revista de Derecho Universidad de Concepción, 1942, nº 41-42, año X, p. 183.

${ }^{31}$ Tapia Suarez, Orlando, De la Responsabilidad Civil en general y de la Responsabilidad Delictual entre los contratantes, Legal Publishing Chile, Santiago, 2009, $3^{\circ}$ edición actualizada, p. 323.

${ }^{32}$ RodríguEz, Pablo, Responsabilidad Extracontractual, Editorial Jurídica de Chile, Santiago, 2002, p. 485 .
} 
En este sentido, siguiendo la "tesis tradicional" y sosteniendo que la prescripción del artículo 2332 no se suspende, se ha pronunciado al profesor DomínguEz ÁguILA, quien sostiene que:

"en verdad la cuestión no nos parece que pueda ser resuelta sólo con aquellos argumentos fundados en la letra de la ley. Si el art. 2524 alude a "actos y contratos", no puede de allí derivarse la conclusión de que, porque los delitos y cuasidelitos no lo son, su prescripción deba suspenderse por recuperar imperio el art. 2520 en relación con el art. $2509 N^{\circ}$ 1. La suspensión es un favor que la ley concede y requiere de norma especial. El artículo 2520 no es una regla general para toda prescripción, sino para la tratada en el párrafo 2 del Título XLII del Libro IV, esto es la ordinaria de cinco años y la ejecutiva de tres, y si no hay regla especial que ordene la suspensión, no es posible aplicar la regla que no se haya dispuesto este caso". ${ }^{33}$

En el mismo sentido, RioseCo EnRíQuez. ${ }^{34}$

En una opinión contraria, que denominaré "tesis moderna", se advierte como gran precursor de la aplicación de la suspensión a la prescripción de la acción de responsabilidad extracontractual al profesor BARROS BOURIE, quien concluye que:

"en verdad, la suspensión parece ser una institución general de protección, justificada en la incapacidad de ciertas personas, más que un favor excepcional conferido por la ley. Así, los casos en que la prescripción corre en contra de toda clase de personas constituyen más bien las excepciones. En la medida que las excepciones debieran ser interpretadas restrictivamente, resulta preferible la opinión que sostiene que la acción de responsabilidad se suspende a favor de las personas enumeradas en los números $1^{\circ}$ y $2^{\circ}$ del artículo 2509. Más aún, desde un punto de vista teleológico, si se considera que las razones para que rija la suspensión respecto de acciones ordinarias y ejecutivas son también pertinentes, al menos con el mismo peso, respecto de la acción de responsabilidad civil extracontractual". ${ }^{35}$

\footnotetext{
${ }^{33}$ Domínguez, cit. (n. 3), p. 369.

${ }^{34}$ Rioseco, cit. (n. 9), p. 86.

${ }^{35}$ Barros, Enrique, Tratado de Responsabilidad Extracontractual, Editorial Jurídica de Chile, Santiago, 2020, $2^{\circ}$ ed. actualizada, T. II, p. 1037.
} 
En el mismo sentido el profesor PizARro; ${ }^{36}$ por otra parte, el profesor CORRAL también se inclina a favor de esta postura, sin embargo, no se pronuncia mayormente. ${ }^{37}$

En suma, la tesis tradicional, se funda principalmente en el carácter excepcional de la suspensión, la ubicación del artículo 2520, y en la falta de regla especial que ordene la suspensión del plazo contemplado en el artículo 2332. En cambio, la tesis moderna, respalda la aplicación de la suspensión de la prescripción a la acción de responsabilidad extracontractual fundada en su carácter protector, así como en la justicia que resulta de su aplicación.

4. Así las cosas, es posible concluir que el tratamiento doctrinario sobre la materia es escaso, pues aquellos autores que se han detenido en el punto únicamente ofrecen un breve panorama del estado jurisprudencial a la fecha de sus respectivos trabajos, sin realizar un análisis exhaustivo de los fundamentos de la institución.

Sin embargo, a partir de los autores citados en el punto anterior, se desprenden claramente dos tesis contrapuestas: aquellos que rechazan la suspensión de la prescripción de la acción aquiliana fundándose en la sistemática del Código ("tesis tradicional"); y aquellos que la aceptan fundamentalmente por razones de justicia ("tesis moderna").

Corresponde ahora a analizar lo que ha sostenido la Excelentísima Corte Suprema.

\section{El problema ante la jurisprudencia nacional: una dicotomía}

Ciertamente, la jurisprudencia que ha analizado el punto resulta más abundante en comparación a los pronunciamientos que ha emitido la doctrina, pero aun así, como se advertirá, mantiene oscuridad respecto a la solución.

Estimo que el hecho de que el volumen jurisprudencial sea mayor a

\footnotetext{
${ }^{36}$ El autor trató brevemente la controversia en una exposición realizada en las jornadas de Derecho Civil del año 2015 en la Universidad de Concepción. En dicha oportunidad, el profesor PIZARRo se inclinó por la tesis del profesor BARROS BOURIE; debiendo destacarse, por lo demás, que es el único trabajo doctrinario encontrado en que se trata exclusivamente el tema. PizArRo, Carlos, "Acerca de la suspensión del término de prescripción de la acción de responsabilidad civil extracontractual”, en: Barría, M. (Coord.), Estudios de Derecho Civil XI, Legal Publishing Thomson Reuters, Santiago, 2016, p. 913-919.

${ }^{37}$ Corral, Hernán, Lecciones de Responsabilidad Civil Extracontractual, Editorial Jurídica de Chile, Santiago, 2004, p. 351. Tiempo después, reafirmaría su postura en un análisis jurídico en el sitio web del Mercurio Legal, en: CORRAL, Hernán, “¿Se suspende la prescripción de la acción por daños extracontractuales a favor de los menores de edad?", 2016, disponible en: https://www.elmercurio.com/legal/noticias/analisisjuridico/2016/04/25/se-suspende-la-prescripcion-de-la-accion-por-danos-extracontractuales-en-favor-demenores-de-edad.aspx, consultada: 19 de julio 2020.
} 
los pronunciamientos doctrinarios sobre la materia, se debe a la frecuente aplicación práctica que el estatuto de la responsabilidad extracontractual recibe en los hechos, así como a los numerosos casos en que la víctima del daño resulta ser una persona incapaz (principalmente menores en calidad de herederos, o bien, como víctimas por repercusión en aquellos casos en que alegan su propio daño).

En esta oportunidad me limitaré a analizar la jurisprudencia de la Corte Suprema en los últimos 10 años. ${ }^{38-39}$

En estas sentencias es posible identificar, al igual que en doctrina, dos grandes posiciones:

A.- Tesis tradicional: jurisprudencia que rechaza la suspensión de la prescripción de la acción de responsabilidad extracontractual

Los principales argumentos de la jurisprudencia referida, para rechazar la suspensión de la prescripción de la acción de responsabilidad extracontractual, pueden ser sintetizados de la siguiente manera:

\section{A.1.- La ubicación de las normas de la suspensión}

La Corte ha indicado que las normas de suspensión de la prescripción extintiva, al estar tratadas en el mismo párrafo de la prescripción de las acciones ordinarias, y después de que el Código se refiriera a las mismas (como regla de cierre), únicamente regiría respecto de aquellas acciones, mas no de las especiales que prescriben en corto tiempo, cuestión que sería concordante con lo dispuesto en el artículo 2524 en orden a que esta clase de prescripciones corren en contra de toda persona, salvo texto expreso.

De esta forma, se ha señalado que:

“(...) la suspensión de la prescripción está regulada en el Párrafo

\footnotetext{
${ }^{38}$ Pronunciándose en contra de la suspensión: 1.- Corte Suprema, 16 de marzo de 2012, Rol № 88982009; 2.- Corte Suprema, 11 de julio de 2012, Rol No 8879-2010; 3.- Corte Suprema, 4 de abril de 2016, Rol No 3952-2015; 4.- Corte Suprema, 3 de abril de 2017, Rol No 18.306-2016; 5.- Corte Suprema, 19 de abril de 2018, Rol No 12221-2017; 6.- Corte Suprema, 21 de junio de 2017, Rol No 101758-2016. Pronunciándose en favor de la suspensión: 1.- Corte Suprema, 3 de noviembre de 2014, Rol № 184562014; 2.- Corte Suprema, 20 de junio de 2016, Rol No 9.333-2015; 3.- Corte Suprema, 14 de julio de 2016, Rol No 11.085-2015: 4.- Corte Suprema, 4 de septiembre de 2017, Rol No 397-2017; 5.- Corte Suprema, 8 de marzo de 2018, Rol No 35.764-2017; 6.- Corte Suprema, 12 de junio de 2019, Rol No 4.288-2019; 7.- Corte suprema, 10 de octubre de 2019, Rol No 4.579-2018.

${ }^{39}$ Para la búsqueda de las sentencias se utilizó tanto la base de datos de jurisprudencia del Poder Judicial de Chile (en: http://basejurisprudencial.poderjudicial.cl/), como de las plataformas digitales Westlaw Chile de la editorial Thomson Reuters (en: https://westlawchile.cl/) y de Vlex Chile (en: https://vlex. $\mathrm{cl} /$ ).
} 
$2^{\circ}$ del Título XLII del Libro IV del Código Civil, a propósito de la prescripción adquisitiva ordinaria, especificamente en el artículo 2509, que dispone este beneficio en sus numerales $1^{\circ}$ y $2^{\circ}$ a favor de los menores y las mujeres casadas en sociedad conyugal. A continuación, el Párrafo $3^{\circ}$ del mismo título contiene la normativa general relativa a la prescripción extintiva, señalándose en el artículo 2515 que el tiempo para que opere tal prescripción es en general de tres años para las acciones ejecutivas y de cinco años para las acciones ordinarias. En esta regulación de la acción ordinaria de cinco años se contienen también reglas generales, atingentes a la misma acción, en lo que toca a la interrupción y suspensión de la prescripción. Especificamente el artículo 2520 dispone: "La prescripción que extingue las obligaciones se suspende a favor de las personas enumeradas en los números $1^{\circ} y$ $2^{\circ}$ del artículo 2509...”. En el Párrafo siguiente, esto es, en el $N^{\circ} 4$ del Título XLII el Código se norma lo concerniente a la prescripción extintiva de "ciertas acciones que prescriben en corto tiempo", esto es, en un lapso distinto al de cinco años previsto en el artículo 2515. Los dos primeros artículos, 2521 y 2522 pormenorizan determinadas acciones que prescriben en los lapsos que en ellos se indica, y el artículo 2523 establece las modalidades especiales que rigen las situaciones de los dos primeros textos en cuanto a suspensión e interrupción de la prescripción.

Finalmente, el artículo 2524 que contiene la disposición genérica sobre prescripción extintiva de corto tiempo a que están sujetas ciertas acciones, no particulariza ninguna en especial, sino que acude a la regulación que se contenga en los títulos respectivos en que aquéllas se mencionan, pero sí aclara que: "corren también contra toda persona, salvo que expresamente se contenga otra regla”.

Es evidente que la expresión "corren también" es concordante con la mención del inciso $1^{\circ}$ del artículo 2523 que precede a esta norma, en cuanto allí se ha hecho expresa alusión a la suspensión de la prescripción". 40

Si bien no constituye un argumento definitorio del problema, es un factor que debe tenerse necesariamente en consideración al momento de 
emitir un pronunciamiento sobre el mismo, sobre todo si se toma en cuenta el texto de los artículos 2523 y 2524 que, tratándose de las prescripciones de corto tiempo, sostienen que éstas corren en contra de toda persona.

A.2.- El carácter de prescripción especial de corto tiempo que ostenta el plazo del artículo 2332 del Código Civil

$\mathrm{Al}$ respecto, se ha sostenido que como la acción aquiliana, conforme al artículo 2332, tiene un plazo de prescripción inferior a 5 años y a su vez está regulada en un título especial del Código Civil, debe ser calificada como "especial de corto tiempo". Por lo tanto, quedaría sujeta a lo dispuesto en el artículo 2524, no admitiéndose suspensión a su respecto, salvo que la ley expresamente indicase lo contrario.

Así, en razón de su extensión, se ha resuelto que:

“(...) quedan comprendidas en el texto del artículo 2524 del Código Civil, entre otras acciones, las que derivan de los ilícitos civiles, esto es, delitos o cuasidelitos con su especial regulación en el Título XXXV del Libro IV, el pacto comisorio y otras de corto tiempo, que en general no se suspenden, a menos que expresamente se establezca una regla diversa" ${ }^{41}$

A.3.- La finalidad de la prescripción y la excepcionalidad de la suspensión Se ha resuelto que "la conclusión que precede - que no se suspende - armoniza con la finalidad de estabilidad jurídica que inspira a la institución de la prescripción, lo que justifica que la suspensión del plazo sea una situación de excepción y, como tal, de interpretación y aplicación restrictiva a las situaciones especialmente previstas por la ley". ${ }^{42}$

Este razonamiento es concordante con lo que fue señalado a propósito de los aspectos generales de la suspensión de la prescripción, pues es un beneficio, por ende, excepcional, y, como tal, debe ser interpretada y aplicada restrictivamente.

Por otra parte, estimo que se debe tener en consideración que al ser la prescriptibilidad de las acciones la regla general en nuestro derecho, todo aquello que atente contra aquella regla - como las acciones imprescriptibles

\footnotetext{
${ }^{41}$ Corte Suprema, 16 de marzo de 2012, Rol No 8898-2009 (cons. 12º); en mismo sentido: Corte Suprema, 11 de julio de 2012, Rol No 8879-2010 (cons. 16º).

42 Ibídem.
} 
o las instituciones de la interrupción y la suspensión de la prescripción requiere de texto expreso y a la vez de una interpretación restrictiva del mismo.

A.4.- La expresión "acto" utilizada en el artículo 2332 del Código Civil es concordante con la expresión "actos o contratos" del artículo 2524 del mismo cuerpo legal

En respuesta al apegado tenor literal de la tesis moderna, se ha fallado que:

"es erróneo postular que por el hecho de que el artículo 2524 del Código Civil utilice la frase "actos o contratos", no sea posible extender su aplicación a las obligaciones derivadas de los ilícitos civiles. Efectivamente, en el título relativo a la responsabilidad extracontractual el Código emplea indistintamente las expresiones "hechos" o "actos", y es así como el artículo 2332 que regula el plazo de prescripción, señala que el mismo se contará "desde la perpetración del acto". ${ }^{43}$

Lo anterior, concuerda con la opinión que ha sostenido RioseCo ENRíQuez, ${ }^{44}$ para quien la expresión "acto", utilizada en el artículo 2332, es concordante con la expresión "actos o contratos" del artículo 2524, lo cual confirmaría su carácter de prescripción especial de corto tiempo.

B.- Tesis moderna: jurisprudencia que acepta la suspensión de la prescripción de la acción de responsabilidad extracontractual

Los argumentos de estas sentencias pueden sintetizarse en los siguientes:

B.1.- Las únicas prescripciones que no admiten suspensión, son las denominadas "prescripciones de corto tiempo" previstas en los artículos 2521 y 2522, mas no las "prescripciones especiales de corto tiempo" referidas en el artículo 2524

Se ha sostenido que, el artículo 2523 al señalar expresamente que las prescripciones de los artículos 2521 y 2522 "corren contra toda persona,

\footnotetext{
${ }^{43}$ Corte Suprema, 4 de abril de 2016, Rol No 3.952-2015 (cons. $8^{\circ}$ ).

${ }^{44}$ Rioseco, cit. (n. 9), p. 86.
} 
y no admiten suspensión alguna", y al no utilizar la misma expresión el artículo 2524 -que se limita a señalar que las prescripciones especiales "corren también contra toda persona"- se concluiría que las únicas prescripciones que no admiten suspensión serían las primeras, pues fue allí donde el legislador lo señaló expresamente.

En este sentido, luego de referirse a las normas que consagran la suspensión (2509 y 2520) se ha sostenido que:

“(...) tales normas, que contemplan la regla general en materia de suspensión de prescripción, tienen una regla excepcional que inhibe su aplicación, contemplada en el artículo 2523 del Código Civil, que señala que las acciones de corto tiempo no admiten suspensión (...) siendo necesario señalar que la última norma hace una referencia expresa a las acciones tratadas en "los dos artículo precedentes", haciendo una remisión expresa a aquellas reguladas en el Párrafo $N^{\circ} 4$ del Título XLII, del Código Sustancial, cuyo epígrafe reza: "De ciertas acciones que prescriben en corto tiempo", regulándose en los artículos 2521 y 2522 ciertas acciones que prescriben en los plazos de uno, dos y tres años", [agregando que] (...) "en efecto, la restricción prevista en la ley respecto de la aplicación de la suspensión de la prescripción solo afecta a las acciones de corto tiempo que se encuentran dentro del párrafo cuarto del Título XLII del Libro IV del Código Civil, sin que la norma prevista pueda ser interpretada en el sentido de incluir a la prescripción de todas aquellas acciones especiales (...)" ${ }^{45}$

Como se dirá pronto, en mi opinión, se trata de un razonamiento que atenta contra la sistematicidad del Código.

\section{B.2.- El tenor literal del artículo 2524 del Código Civil.}

Con base al argumento gramatical, esta parte de la jurisprudencia ha sostenido que el artículo 2524, al emplear la expresión "actos o contratos", se estaría refiriendo a los actos o negocios jurídicos, es decir, a manifestaciones de voluntad destinadas a producir consecuencias jurídicas, excluyéndose, por lo tanto, a los hechos, como sería el caso de los delitos y cuasidelitos civiles.

\footnotetext{
${ }^{45}$ Corte Suprema, 8 de marzo de 2018, Rol No $35.764-2017$ (cons. $8^{\circ}$ ).
} 
En este sentido, el máximo tribunal, refiriéndose al artículo 2524, ha resuelto que:

"la expresión "acto" está referida, según la dogmática jurídica, al acto jurídico, esto es, al hecho humano llevado a cabo voluntariamente con el fin de producir un efecto jurídico determinado y querido por una persona; características que lo distinguen de los demás hechos humanos voluntarios que, aunque puedan originar efectos jurídicos, ellos no son los perseguidos finalmente por el autor; a esto actos se refieren, entre otros, los artículos 10, 11, 735, 766, 1445 y 1681 del Código Civil". Para luego agregar que "al emplear el legislador en el artículo 2332 del referido Código substantivo el vocablo "acto", lo refiere únicamente al hecho jurídico voluntario realizado sin la intención de producir efectos de derecho, en este caso, delito o cuasidelito. Lo demuestra, sin lugar a dudas, tanto la ubicación de la disposición como el uso que hace del verbo "perpetrar" (perpetración) para señalar el momento de la ejecución del "acto", verbo que, conforme al Diccionario de la Real Academia, significa "cometer" o "consumar" y se aplica sólo a los delitos en general". ${ }^{46}$

En otra sentencia, se ha complementado este postulado sosteniendo que:

“...la circunstancia que el artículo 2332 de ese código emplee la palabra "acto" para referirse al inicio del cómputo de la prescripción extracontractual, debe entenderse que se refiere a un hecho no destinado a producir efectos jurídicos, lo que se grafica con el lugar donde se ubica la norma y la utilización del verbo "perpetrar", lo que significa "cometer", norma que coincide con el articulo $2314 \mathrm{del}$ Código Civil, cuando señala: "El que ha cometido un delito ...". ${ }^{47}$

Sin embargo, como expondré más adelante, en mi opinión, la expresión "actos o contratos" no es excluyente de los delitos y cuasidelitos civiles.

${ }^{46}$ Corte Suprema, 14 de julio de 2016, Rol No 11.085-2015 (cons. $18^{\circ}$ ).

${ }^{47}$ Corte Suprema, 10 de octubre de 2019, Rol No 4579-2018 (cons. $7^{\circ}$ ). Este argumento no es más que una reproducción de un antiguo fallo de la Corte de Santiago, 12 de enero 1988, R.D.J., T. 85, sec. 2, p. 1; confirmada por sentencia de la Corte Suprema, 7 de julio de 1988, F. del M., No 365, p. 120. 
B.3.- Un supuesto carácter general de la institución de la suspensión de la prescripción.

Al respecto, se ha sostenido, amparándose en el carácter protector de la suspensión de la prescripción, que ésta "constituye la regla general dentro de la institución de la prescripción, siendo excepcional la imposibilidad de aplicarla". ${ }^{48}$

Estimo que esta argumentación debe ser desechada, pues como fue expuesto en el acápite de los aspectos generales de la suspensión de la prescripción, se trata de un beneficio personalísimo, que rompe el principio de la prescriptibilidad de la acción, así como la regla común de toda prescripción consistente en que corre por igual contra toda persona (artículo 2497), características que la constituyen en una institución excepcional y que, por lo tanto, requiere de una interpretación y aplicación restrictiva. Este razonamiento, concuerda plenamente con la regulación misma de la institución, así se desprende del hecho de que la suspensión ha sido contemplada en textos expresos (artículos 2509 y 2520) y de los términos perentorios de los artículos 2520, 2509 inciso segundo y 2524 in fine.

\section{B.4.- La finalidad protectora de la institución de la suspensión.}

En gran parte de los fallos en que la Corte se ha pronunciado a favor de la suspensión de la prescripción de la acción de responsabilidad extracontractual, se ha citado textualmente la opinión del profesor BARROS BourIE, quien, como ya fue señalado, sostiene que la suspensión es una institución general de protección, justificada en la incapacidad de ciertas personas, más que un favor excepcional que conceda la ley; y que, por otra parte, desde un punto de vista teleológico, la suspensión de la prescripción de la acción de responsabilidad extracontractual tendría igual fundamento que en materia contractual. ${ }^{49}$

Si bien se trata de una opinión autorizada en la materia y con un claro fundamento protector, estimo que el argumento debe ser rechazado, en base a las siguientes razones:

(i) Como fue señalado, la suspensión es una figura excepcional, de aplicación e interpretación restrictiva. Lo anterior, debido a que la regla general y común a toda prescripción, es que ésta corra en contra de toda persona (artículo 2497), por lo tanto, en realidad, la regla general es la

\footnotetext{
${ }^{48}$ Corte Suprema, 8 de marzo de 2018, Rol No 35.764-2017 (cons. $8^{\circ}$ y $11^{\circ}$ ).

${ }^{49}$ Barros, cit. (n. 35), p. 1037.
} 
prescriptibilidad de la acción, mas no la suspensión;

(ii) No debe desatenderse el hecho de que para el caso de estimarse que la prescripción de la acción aquiliana no se suspenda a favor de las personas enumeradas en el artículo 2509 No 1 y 2 , éstas no quedan en la indefensión, pues tienen a quien los ampare en defensa de sus intereses: en el caso del $\mathrm{N}^{\circ} 1$, a sus respectivos representantes; y en el caso del $\mathrm{N}^{\circ} 2$, la misma mujer casada en sociedad conyugal, que, en principio, es plenamente capaz.

(iii) En cuanto al fundamento teleológico, a mi parecer, se trata de un argumento más aparente que real, por cuanto dentro de la misma responsabilidad contractual se han establecido tanto remedios o acciones que prescriben en corto tiempo y no se suspenden ( $v . g r$. las prescripciones de las acciones edilicias, contempladas en los artículos 1866 y 1869), como otros que prescriben en largo tiempo y sí admiten suspensión ( $v$. gr. la prescripción de la acción de resolución por incumplimiento del artículo 1489 que, al no tener un plazo especial, prescribe y se suspende conforme a los artículos 2514,2515 y 2520 , respectivamente).

Surgen aquí dos preguntas íntimamente relacionadas: ¿Por qué se han contemplado plazos de prescripción más breves que otros? (Como ocurre entre la acción aquiliana y la de responsabilidad contractual; o, sin ir más lejos, como fue señalado, incluso en el mismo ámbito contractual); y ¿Por qué ciertas prescripciones se suspenden y otras no? En mi opinión, se trata de situaciones especiales en que, por sus características, se exige que la acción se ejerza en un plazo breve, ya que de lo contrario la prueba en juicio se tornaría débil; $y$, por otra parte, se trata de situaciones calificadas a las que el legislador ha querido dar estabilidad pronta.

(iv) Por último, si bien es cierto de que pueden existir considerables razones de justicia para aplicar la suspensión en ciertos casos, los textos no pueden ser desatendidos, por lo que en aquellas situaciones en que sea indispensable imponer la suspensión u otra institución protectora que altere la sistematicidad de las reglas de prescripción del derecho común, se requerirá de una reforma legislativa en tal sentido. Así, por ejemplo, ha ocurrido con la denominada "renovación de la acción civil" contemplada en la Ley $\mathrm{N}^{\mathrm{o}}$ 21.160, a propósito de los delitos sexuales cometidos en contra de menores de edad. 


\section{PROPUESTA PERSONAL}

Ya establecidos los aspectos y contornos generales, y en especial, asentados los postulados de que la prescriptibilidad de las acciones es la regla general en nuestro derecho y que, a la inversa, la suspensión - al ser un beneficio jurídico especial - es una institución excepcional que pugna con aquel principio, al establecer la detención del cómputo del plazo a favor de ciertas personas, resulta ahora conveniente referirse a la forma en que, según mi parecer, debe ser abordado adecuadamente el problema consistente en determinar si es que el plazo de prescripción del artículo 2332 admite o no suspensión. ${ }^{50}$

Para lo anterior, propondré la siguiente manera de proceder:

$1^{\circ}$. En primer término, es necesario determinar, conforme al artículo 2524, que se entiende por prescripciones especiales de corto tiempo.

$2^{\circ}$. En segundo lugar, es necesario establecer si es que el hecho de que una prescripción sea calificada como especial de corto tiempo implica de por sí que esta no se suspende, salvo texto expreso, o si, por el contrario, ésta sí se suspende conforme a la regla general prevista en el artículo 2520 del Código Civil.

$3^{\circ}$. Resueltos los puntos anteriores, corresponderá definir si el plazo de prescripción del artículo 2332 es o no especial de corto tiempo conforme al antedicho artículo 2524, con las consecuencias que de ello deriven; y si el hecho de no estimarse así, implica que rija a su respecto el ya citado artículo 2520 .

$4^{\circ}$. Por último, corresponderá hacerse cargo del alcance de la expresión "acciones especiales que nacen de ciertos actos o contratos" contemplada en el artículo 2524.

Como explicaré en los puntos siguientes, las prescripciones especiales de corto tiempo no se suspenden (salvo regla en contrario), siendo una de ellas la contemplada en el artículo 2332 del Código Civil; y aun cuando no lo fuere, se llega a la misma conclusión.

\footnotetext{
${ }^{50}$ Es necesario señalar, a modo de prevención, que el hecho de estimar que el plazo contemplado en el artículo 2332 no se suspenda, no lo transforma en uno de caducidad. Lo anterior, debido a la literalidad del precepto al utilizar la expresión "prescriben"; y, además, porque la caducidad requiere de una disposición legal expresa que la contemple, tanto por la repercusión que produce al momento de operar (exinción de un derecho), como por sus propias características, tales como: es irrenunciable, debe ser declarada de oficio por el tribunal, no se suspende, tampoco se interrumpe, entre otras. (Para ahondar en las diferencias entre la caducidad y la prescripción, puede verse: DomínGuEZ, cit. (n. 3), p. 140-146).
} 
$1^{\circ}$ ¿Qué se entiende por "prescripciones especiales de corto tiempo”?

Según se desprende del texto del artículo 2524, la norma exige tres requisitos para que una prescripción pueda ser considerada como especial de corto tiempo, a saber:

i.-Que la prescripción sea de “corto tiempo”, lo cual, según la doctrina común, como ya fue señalado, significa que su plazo de prescripción sea inferior a 5 años;

ii.- Que se encuentre establecida en un título especial del Código Civil, distinto al de la prescripción; y

iii. Que la acción especial que prescribe nazca de un acto o de un contrato.

De esta forma, es posible definir a esta clase de prescripciones como aquellas que, naciendo de ciertos actos o contratos, se encuentran reguladas en un título especial del Código Civil y su extensión es inferior a 5 años.

Establecidos estos contornos, es necesario responder la pregunta que sigue.

$2^{\circ}$ ¿ Es efectivo que las prescripciones especiales de corto tiempo no admiten suspensión?

Tradicionalmente se ha sostenido que, en virtud de la expresión utilizada por el legislador en el artículo 2524, al señalar que las prescripciones especiales de corto tiempo "corren también contra toda persona; salvo que expresamente se establezca otra regla", se habría querido significar que dichas prescripciones no se suspenden, salvo disposición en contrario.

Sin perjuicio de lo anterior, como ya fue expuesto, existe una parte de la doctrina (aunque minoritaria) y de la jurisprudencia que no comparte esta afirmación, pues sostienen que la expresión del legislador no ha querido significar la exclusión de la suspensión y que, por lo tanto, las prescripciones especiales sí se suspenden conforme a la regla general contemplada en el artículo 2520 del Código Civil. ${ }^{51}$ Lo anterior, en base a dos grandes argumentos:

(i) El artículo 2523, utilizó, a propósito de las prescripciones de corto tiempo propiamente tales (reguladas en los artículos 2521 y 2522), la expresión "corren contra toda clase de personas, y no admiten suspensión alguna”, expresión que no se empleó de igual manera en la redacción del artículo 2524, que simplemente se limitó a señalar que las prescripciones

${ }^{51}$ Pizarro, cit. (n. 36), p. 913-919. 
especiales "corren también contra toda persona".

En otros términos, argumentan que el artículo 2523 señala expresamente que las prescripciones de los artículos 2521 y 2522 no admiten suspensión; en cambio, no ocurrió lo mismo en el artículo siguiente que, tratándose de las prescripciones especiales de corto tiempo, no excluyó expresamente la suspensión.

(ii) Por otra parte, sostienen que la expresión "corren también contra toda persona" del artículo 2524, sólo habría querido excluir de ellas la distinción entre presentes y ausentes que existía al tiempo de la dictación del Código Civil en el antiguo texto del artículo 2508. Así, atribuyen la expresión a un simple resabio legislativo.

En una primera aproximación, los argumentos de esta posición parecen atractivos. Sin embargo, estimo que, tal como lo ha sostenido la doctrina tradicional, la expresión "corren también en contra de toda persona", empleada en el artículo 2524, significa que la prescripción no se suspende. Así se desprende de las siguientes consideraciones:

a.- Si es que se estimase que las prescripciones especiales en realidad se suspenden conforme a la regla general del artículo 2520, no tendría coherencia alguna que ciertos artículos del Código, que contemplan prescripciones especiales, dispongan expresamente que algunas de ellas se suspenden, como es el caso de las acciones de nulidad relativa (artículos 1691 y 1692) y de reforma de testamento (artículo 1216).

En otras palabras, de seguirse la tesis contraria, se rompería con la sistematicidad del Código, pues aquellos artículos en que se ha dispuesto expresamente la suspensión de prescripciones especiales no serían más que repeticiones inútiles de la regla general dispuesta en el artículo 2520 .

Siguiendo este razonamiento, la única manera de darle sentido a estos preceptos, en que se contemplan normas de suspensión, es sosteniendo que constituyen una excepción a la regla general contraria, esto es, que dichas prescripciones no admiten suspensión, salvo texto expreso, lo que a su vez concuerda con la expresión final del artículo 2524.

b.- Por otra parte, el texto del artículo 2524 debe ser considerado en su integridad. En efecto, luego de señalar que las prescripciones especiales corren también contra toda persona, agrega "salvo que expresamente se establezca otra regla”. Entonces, ¿Cuál es el alcance de dicha frase? A mi parecer, la respuesta es categórica: se refiere a que aquellas prescripciones sólo se suspenden cuando la ley lo dispone. De no entenderse así, la expresión carecería de toda utilidad. 
Lo anterior concuerda con los casos excepcionales de suspensión de los artículos 1692 y 1216.

c.- Por último, corresponde ahora hacerse cargo de los argumentos de la tesis contraria:

c.1.- En lo que respecta a la primera cuestión, esto es, determinar el por qué el legislador al referirse a las prescripciones de corto tiempo propiamente tales en el artículo 2523 utilizó la expresión "corren contra toda clase de personas, y no admiten suspensión alguna", estimo que simplemente se trata de un reforzamiento (pleonasmo) o una expresión redundante como otras que ha empleado el codificador al regular ciertas materias (v. gr. "exclusiva y solidariamente responsable de todo perjuicio" en el artículo 1526; "obligación personal" en el artículo 2465; o sin ir más lejos la expresión "lapso de tiempo" utilizada en los artículos 2511, 2514, 716,1683 , etc.) En este sentido, como sostenían Alessandri, Somarriva y VODANOVIC, a propósito de otras expresiones del legislador, "los pleonasmos a veces son útiles por dar colorido o fuerza expresiva a las frases". 52

c.2.- Ahora, en lo que respecta al segundo argumento de la tesis contraria, en mi opinión, también debe ser rechazado. Lo anterior, porque la distinción entre ausentes y presentes que se contenía en el texto original del artículo 2508, se encontraba establecida para la prescripción adquisitiva, mas no para la extintiva, que es donde se encuentra emplazado el artículo 2524.

A mayor abundamiento, es necesario agregar que el artículo 822 del Código de Comercio, al referirse a las prescripciones extintivas allí tratadas, contiene igual expresión ("corren contra toda persona") y en él no se distinguen plazos entre ausentes o presentes, y por lo tanto, es claro que se refiere a que no se suspenden.

Llegado este punto, resta determinar si la prescripción de la acción de responsabilidad extracontractual debe o no ser calificada como especial de corto tiempo.

$3^{\circ}$. ¿Es efectivamente la prescripción contemplada en el artículo 2332 una prescripción especial de corto tiempo en los términos del artículo 2524 ?

Me inclino por la afirmativa, pues se cumplen todos los requisitos exigidos por el artículo 2524 para que ésta sea estimada como especial

${ }^{52}$ Alessandri, Arturo; Somarriva, Manuel; Vodanovic, Antonio, Tratado de Derecho Civil. Partes preliminar y general, Editorial Jurídica de Chile, Santiago, 2005, $7^{\circ}$ ed. actualizada, T. II, p. 65. 
de corto tiempo, en efecto: $1^{\circ}$. Se encuentra regulada en un título especial del Código Civil, esto es, en el Título XXXV del Libro IV; $2^{\circ}$. Su plazo es inferior al de las prescripciones ordinarias, pues es de 4 años contados desde la perpetración del acto; y $3^{\circ}$. Es una acción especial que nace de un acto, pues está dirigida específicamente a obtener una indemnización de perjuicios provenientes de un hecho ilícito. Ahora bien, este último punto requiere un apartado especial.

$4^{\circ}$. Alcance de la expresión "acciones especiales que nacen de ciertos actos o contratos" del artículo 2524 del Código Civil

Como fue indicado en el análisis doctrinario y jurisprudencial, uno de los argumentos de la tesis moderna para excluir a la prescripción del artículo 2332 del ámbito de aplicación del artículo 2524 y, por consiguiente, no calificarla como especial de corto tiempo, radica en que este último artículo se refiere a las "acciones especiales que nacen de ciertos actos o contratos" utilizando la expresión como sinónimo de "actos jurídicos" excluyéndose, por lo tanto, los hechos como sería el caso de los delitos o cuasi delitos civiles. Así, sostienen que, al no nacer la acción de responsabilidad extracontractual de un acto jurídico, su prescripción no sería subsumible en el artículo 2524.

Sin embargo, en mi opinión, la acción especial que emana de un delito o cuasidelito civil sí queda comprendida en la expresión empleada por el legislador en el artículo en comento; y aún para el caso de estimarse lo contrario, la prescripción del artículo 2332 tampoco se suspende. Lo anterior, en base a las siguientes consideraciones:

a.- La expresión "ciertos actos o contratos" que emplea el artículo 2524 no está circunscrita ni orientada a los actos jurídicos.

En efecto, como señala el profesor VIAL DEL Río, nuestro Código Civil no acogió ni reguló una figura general del acto jurídico, es más, desconoció el término. ${ }^{53}$

En este sentido, es necesario agregar que el Código tampoco contiene una definición de "acto". Por consiguiente, conforme a lo previsto en su artículo 20, aquella palabra debe ser entendida en su sentido natural y obvio, según el uso general de la misma, contenido en el Diccionario de la Real Academia, según el cual se debe entender por "acto" a la "acción o ejercicio

${ }^{53}$ Vial, Víctor, Teoría general del acto jurídico, Editorial Jurídica de Chile, Santiago, 2006, $5^{\circ}$ ed. actualizada, p. 11. 
de la posibilidad de hacer", ${ }^{44}$ quedando, por lo tanto, comprendidos en dicha expresión tanto los actos como los hechos jurídicos.

En suma, se trata de un término omnicomprensivo.

b.- Por otra parte, es necesario agregar que existe un conjunto de otras disposiciones legales en que el legislador ha utilizado la expresión "acto" o "actos" para referirse indistintamente a hechos ( $v$. gr. artículos 920 y 929 a propósito de las acciones posesorias; ${ }^{55}$ y otro tanto ocurre en el artículo 885 $\mathrm{N}^{\mathrm{o}} 5$ inciso 2, a propósito de la extinción por tiempo de las servidumbres continuas).

c.- Por lo demás, el propio artículo 2332 contiene la expresión, al señalar que la acción prescribe en cuatro años contados desde la perpetración del "acto", la cual es concordante con la expresión "actos" utilizada en el artículo 2524. El profesor Rioseco EnRíQueZ se ha pronunciado en igual sentido. ${ }^{56}$

Así, al ser claro el sentido de la ley, no puede desatenderse su tenor literal, a pretexto de consultar su espíritu, tal como lo prescribe el artículo 19 del Código Civil.

d.- Por último, es necesario hacer presente que aún para el caso de estimarse que la acción de responsabilidad extracontractual no queda comprendida dentro de la expresión "acciones especiales que nacen de ciertos actos o contratos" contenida en el artículo 2524, ésta de todas maneras no admite suspensión alguna, pues, como ha indicado el profesor Domínguez Águila:

"Si el art. 2524 alude a "actos y contratos", no puede de alli derivarse la conclusión de que, porque los delitos y cuasidelitos no lo son, su prescripción deba suspenderse por recuperar imperio el art. 2520 en relación con el art. $2509 N^{\circ} 1$. La suspensión es un favor que la ley concede y requiere de norma especial. El artículo 2520 no es una regla general para toda prescripción, sino para la tratada en el párrafo 2 del Título XLII del Libro IV, esto es la ordinaria de cinco años y la ejecutiva de tres, y si no hay regla especial que ordene la suspensión,

\footnotetext{
${ }^{54}$ Real Academia Española, 2020, disponible en: https://dle.rae.es/?w=acto, consultada: 19 de julio 2020.

${ }^{55}$ En este punto conviene tener presente que las acciones posesorias tradicionalmente han sido calificadas y tratadas como "prescripciones especiales de corto tiempo" - a pesar de nacer de un hecho: la turbación, embarazo o privación de la posesión - y que, por lo tanto, no se suspenden. En este sentido, a modo de ejemplo: Corte Suprema, 26 de junio de 2008, Rol No 2.350-2007.
}

${ }^{56}$ Rioseco, cit. (n. 9), p. 87. 
no es posible aplicar la regla que no se haya dispuesto este caso", ${ }^{57}$

$5^{\circ}$. Otras consideraciones para rechazar la suspensión de la acción de responsabilidad extracontractual

Ya definida mi postura, es necesario agregar un par de aspectos que estimo de importancia y que deben ser tomados en consideración para rechazar la suspensión de la prescripción aquiliana:

$1^{\circ}$. Como se señaló al analizar el artículo 2520, el legislador ubicó dicha norma en el mismo párrafo en que trató las prescripciones extintivas de largo tiempo, lo que constituye es una clara manifestación de que sólo se aplica a su respecto, pues de no seguirse este razonamiento, ¿Cómo se explicaría entonces que 4 normas más adelante, el legislador, después de fijada la regla de la suspensión, se refiriera a otro tipo de prescripciones (de corto tiempo), y, a mayor abundamiento, haya expresado que ellas "corren también contra toda persona; salvo que expresamente se establezca otra regla"?

$2^{\circ}$. Por otra parte, de seguirse la tesis moderna, la prescripción extracontractual se suspendería a favor de la mujer casada en sociedad conyugal mientras dure ésta (artículo 2509 № 2 en relación al artículo 2520). Pues bien, ¿Cuál sería el fundamento, en el caso de una mujer víctima de un daño extracontractual, para suspender la prescripción a su favor en razón del régimen en que se encuentra casada? Estimo que ninguna, pues la norma del artículo 2520, que aplica la suspensión de la prescripción extintiva a favor de la mujer casada en sociedad conyugal, está pensada para las prescripciones de largo tiempo en el ámbito contractual, con el objeto de ponerla a cubierto de una eventual mala administración por parte del marido.

Para graficar lo injustificado que resulta aplicar a todo trance el artículo $2509 \mathrm{~N}^{\mathrm{o}} 2$ a la responsabilidad aquiliana, piénsese en la siguiente hipótesis: una mujer, mayor de edad, el 1 de enero del año 2000 en virtud del actuar negligente de un tercero es víctima de un accidente que le ocasiona graves perjuicios. En esta hipótesis la acción de daños prescribiría en 4 años desde la perpetración del acto, es decir, expiraría el 1 de enero de 2004. Sin embargo, si la mujer pocos días antes contrae matrimonio en sociedad conyugal (por ejemplo, el 20 de diciembre del 2003) se suspendería a su favor la prescripción sin mayor cuestión, deteniéndose el cómputo del plazo en su beneficio. Este razonamiento conduce a rechazar la aplicación

${ }^{57}$ Domínguez, cit. (n. 3), p. 369. 
del precepto, pues la suspensión - en su carácter protector y de beneficio jurídico - no estaría cumpliendo finalidad subjetiva alguna.

\section{CONCLUSIONES}

1.- Si bien existen textos trascendentales de nuestros autores, tanto en materia de prescripción extintiva como de responsabilidad extracontractual, no se ha tratado con estricto rigor científico el problema relativo a si la prescripción de la acción de responsabilidad extracontractual admite o no suspensión.

De esta forma, las principales opiniones doctrinarias sobre la materia, se desprenden de aquellos textos generales y están constituidas, por un lado, por la tesis tradicional defendida principalmente por el profesor DomínGUEZ Águila y, en otro extremo, por la tesis moderna sustentada por el profesor BARROS BOURIE.

Por lo demás, la mayoría de los autores, sin advertir que el punto es discutido, se inclinan por calificar derechamente a la prescripción de la acción de responsabilidad extracontractual del artículo 2332 como "especial de corto tiempo" quedando comprendida en el artículo 2524, agregando que, por lo tanto, ésta no se suspende.

Empero, quien mayormente se ha encargado de desarrollar el problema y sus posibles soluciones, no ha sido la doctrina, sino que la jurisprudencia de nuestros tribunales.

2.- Teniendo en cuenta la jurisprudencia de la Excelentísima Corte Suprema de los últimos 10 años a la fecha de este trabajo, se advierten con claridad dos grandes posiciones antagónicas respecto a la posibilidad de que la prescripción de la acción indemnizatoria derivada de la responsabilidad extracontractual se suspenda a favor de las personas señaladas en los números 1 y 2 del artículo 2509, por aplicación del artículo 2520.

En este sentido, del análisis de los fallos citados se desprende que la Corte Suprema no ha logrado sentar una jurisprudencia uniforme sobre el punto y que, si bien la última sentencia dictada a la fecha sobre el tema investigado se inclina a favor de la suspensión, aquello está lejos de significar que ese sea el criterio uniforme de nuestro máximo tribunal.

3.- Como otro aspecto de la cuestión, después de examinar acabadamente la institución de la suspensión de la prescripción, los artículos del Código Civil que se ven en conflicto tratándose del problema 
investigado, así como las posiciones doctrinarias y jurisprudenciales que existen al respecto, estimo que el modo adecuado de abordar el problema es determinando qué se entiende por prescripciones especiales de corto tiempo, definir si estas realmente se suspenden o no, y, finalmente, precisar si es que la prescripción contenida en el artículo 2332 tiene o no dicho carácter.

En conclusión, de un adecuado análisis dogmático y sistematizado de las normas del Código, se colige que las prescripciones especiales de corto tiempo son aquellas que nacen de ciertos actos o contratos, se encuentran reguladas en un título especial del Código Civil y su extensión es inferior a 5 años; que estas no se suspenden, salvo texto expreso en contrario; que la prescripción contemplada en el artículo 2332 es una de ellas y que, por lo tanto, queda sujeta a la regulación contemplada en el artículo 2524.

Desde otro ángulo, estimo que, de seguirse la "tesis moderna", se produciría un abierto error de Derecho que podría ser decisivo al momento de fallar un asunto.

4.- Por último, es posible afirmar que la discusión está lejos de ser un tema superficial o despreciable, y que la aplicación de una u otra posición trae aparejada importantes consecuencias en lo que respecta al ejercicio de la acción de responsabilidad extracontractual.

\section{BIBLIOGRAFÍA CITADA}

\section{a) Doctrina}

Abeliuk, René, Las Obligaciones, Editorial Jurídica de Chile, Santiago, 2007, $5^{\circ}$ ed. actualizada, T. I - II.

Alessandri, Arturo, De la Responsabilidad Extracontractual en el Derecho Civil Chileno, Imprenta Universitaria, Santiago, 1943.

Alessandri, Arturo; Somarriva, Manuel, Los Bienes y los Derechos Reales, Editorial Nascimento, Santiago, 1974, $3^{\circ}$ ed. ampliada y actualizada.

Alessandri, Arturo; Somarriva, Manuel; Vodanovic, Antonio, Tratado de derecho civil partes preliminar y general, Editorial Jurídica de Chile, Santiago, $2005,7^{\circ}$ ed. actualizada.

Barrientos, Javier, Código Civil, concordancias, historia de la ley, jurisprudencia, Legal Publishing, Santiago, 2012.

Barros, Alfredo, Curso de Derecho Civil, Editorial Nascimento, Santiago, 1932, $4^{\circ}$ ed. corregida y aumentada, T. II.

BARros, Enrique, Tratado de Responsabilidad Extracontractual, Editorial 
Jurídica de Chile, Santiago, 2020, $2^{\circ}$ ed. actualizada, T. II.

Contreras, Luis, "De la Prescripción Extintiva Civil", memoria de prueba, Universidad de Chile, Santiago, publicada, 1945.

CORRAL, Hernán, ¿Se suspende la prescripción de la acción por daños extracontractuales a favor de los menores de edad?, 2016, disponible en: https:// www.elmercurio.com/legal/noticias/analisis-juridico/2016/04/25/se-suspende-laprescripcion-de-la-accion-por-danos-extracontractuales-en-favor-de-menores-deedad.aspx, consultada: 19 de julio 2020.

Corral, Hernán, Lecciones de Responsabilidad Civil Extracontractual, Editorial Jurídica de Chile, Santiago, 2004.

Domínguez, Ramón, La Prescripción Extintiva, doctrina y jurisprudencia, Editorial Jurídica de Chile, Santiago, 2004.

Domínguez, Ramón, "Comentarios de jurisprudencia. Prescripción en materia de responsabilidad extracontractual: Momento de inicio del cómputo. Art. 2332 del Código Civil. Perpetración del acto. Distinción entre hecho ilícito y daño. Daños continuados", Revista de Derecho Universidad de Concepción, N ${ }^{0} 210$, 2001.

Elorriaga, Fabián, "Del día de inicio del plazo de prescripción de una acción indemnizatoria cuando el perjuicio se ha manifestado con posterioridad al hecho que lo origina", en: Corral, H. (ed.), Prescripción extintiva. Estudios sobre su procedencia y funcionamiento en Derecho Público y Privado, Cuadernos de extensión jurídica 21, Universidad de los Andes, Santiago, 2011.

FERRADA, Luis, "La interpretatio per aliam legem como regla para definir el sentido del artículo 2332 del Código Civil, sobre prescripción de la acción de responsabilidad extracontractual", Revista de Derecho Escuela de Postgrado, 2012, $\mathrm{N}^{\mathrm{o}} 2$.

Fueyo, Fernando, Derecho Civil, Imprenta Universo, Santiago, 1958, T. IV.

MezA, Ramón, Manual de Derecho Civil: de las obligaciones, Editorial Jurídica de Chile, Santiago, 2007.

PeñAILILlo, Daniel, Los bienes la propiedad y otros derechos reales, Editorial Jurídica de Chile, Santiago, 2006.

Peñallillo, Daniel, Obligaciones, Teoría general y clasificaciones, La resolución por incumplimiento, Editorial Jurídica de Chile, Santiago, 2003.

Pizarro, Carlos, “Acerca de la suspensión del término de prescripción de la acción de responsabilidad civil extracontractual”, en: Barría, M. (coord.), Estudios de Derecho Civil XI, Legal Publishing Thomson Reuters, Santiago, 2016.

Planiol, Marcel; RIPERT, Georges, Tratado práctico de derecho civil francés, Cultural S.A., La Habana, 1936.

Ramos, René, De la responsabilidad extracontractual, Legal Publishing, Santiago, $2009,5^{\circ}$ ed. actualizada.

Ramos, René, De las obligaciones, Legal Publishing, Santiago, 2008, $3^{\circ}$ ed. 
actualizada.

Rioseco, Emilio, La Prescripción Extintiva ante la Jurisprudencia, Editorial Jurídica de Chile, Santiago, 1994.

Rodríguez, Pablo, Responsabilidad Extracontractual, Editorial Jurídica de Chile, Santiago, 2002.

TAPIA SuAREZ, Orlando, "La Responsabilidad Extracontractual (continuación)", Revista de Derecho Universidad de Concepción, 1942, № 41-42, año $\mathrm{X}$.

TAPia SuÁrez, Orlando, De la Responsabilidad Civil en general y de la Responsabilidad Delictual entre los contratantes, Legal Publishing Chile, Santiago, 2009.

VIAL, Víctor, Teoría general del acto jurídico, Editorial Jurídica de Chile, Santiago, 2006, $5^{\circ}$ ed. actualizada.

Vergara, José, "Aceptación jurisprudencial de la doctrina de que la prescripción extintiva de la responsabilidad extracontractual empieza a correr desde la perpetración del acto ilícito y no a contar de la producción del daño", en: Corral, H. (ed.), Prescripción extintiva Estudios sobre su procedencia y funcionamiento en Derecho Público y Privado, Cuadernos de extensión jurídica 21, Universidad de los Andes, Santiago, 2011.

\section{b) Jurisprudencia citada}

Corte de Apelaciones de Santiago, 12 enero 1988, R.D.J., T. 85, sec. 2, p. 1.

Corte de Apelaciones de Santiago, 7 julio 1988, R.D.J., T.85, sec. $2^{\circ}$, p. 63.

Corte de Apelaciones de Santiago, 5 de diciembre de 2011, Legal Publishing: 56905.

Corte Suprema, 25 mayo 1948, R.D.J., T. 45, sec. I, p. 581.

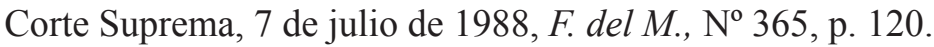

Corte Suprema, 26 de junio de 2008, Rol No 2.350-2007.

Corte Suprema, 16 de marzo de 2012, Rol No 8898-2009.

Corte Suprema, 11 de julio de 2012, Rol No 8879-2010.

Corte Suprema, 3 de noviembre de 2014, Rol No 18456-2014.

Corte Suprema, 4 de abril de 2016, Rol No 3952-2015.

Corte Suprema, 3 de abril de 2017, Rol No 18.306-2016.

Corte Suprema, 19 de abril de 2018, Rol No 12221-2017.

Corte Suprema, 21 de junio de 2017, Rol No 101758-2016.

Corte Suprema, 20 de junio de 2016, Rol No 9.333-2015.

Corte Suprema, 14 de julio de 2016, Rol No 11.085-2015.

Corte Suprema, 4 de septiembre de 2017, Rol No 397-2017.

Corte Suprema, 8 de marzo de 2018, Rol No 35.764-2017.

Corte Suprema, 12 de junio de 2019, Rol No 4.288-2019.

Corte suprema, 10 de octubre de 2019, Rol Nº.579-2018. 
c) Fuentes legales citadas.

Código Civil.

Código de Comercio.

Ley $\mathrm{N}^{\mathrm{o}}$ 6.162. Diario Oficial, 28 de enero de 1938.

Ley $\mathrm{N}^{\mathrm{o}} 16.952$. Diario Oficial, $1^{\circ}$ de octubre de 1968.

Ley $\mathrm{N}^{\circ}$ 18.802. Diario Oficial, 9 de junio de 1989.

Ley N $\mathrm{N}^{\mathrm{o}} 21.160$. Diario Oficial, 18 de julio de 2019. 